\title{
Eyelid Carcinoma pT2a TNM Finding v8
}

National Cancer Institute

\section{Source}

National Cancer Institute. Eyelid Carcinoma pT2a TNM Finding v8. NCI Thesaurus. Code C140494.

Eyelid carcinoma with tumor measuring more than $10 \mathrm{~mm}$ but $20 \mathrm{~mm}$ or less in greatest dimension without invasion of the tarsal plate or eyelid margin. (from AJCC 8th Ed.) 